\title{
Brand Management and Business Performance in Mexican Small Business
}

\author{
Gonzalo Maldonado-Guzman ${ }^{1}$, Jesús Francisco Mellado-Siller ${ }^{2} \&$ Edith Reyes-Ruiz ${ }^{2}$ \\ ${ }^{1}$ Centro de Ciencias Económicas y Administrativas, Universidad Autonoma de Aguascalientes, Mexico \\ ${ }^{2}$ Facultad de Mercadotecnia, Universidad Autónoma de Coahuila, México \\ Correspondence: Gonzalo Maldonado-Guzman, Centro de Ciencias Económicas y Administrativas, Universidad \\ Autonoma de Aguascalientes, Aguascalientes, Mexico.
}

Received: June 28, 2018 Accepted: July 18, 2018 Online Published: August 21, 2018

doi:10.5539/jms.v8n3p16 URL: https://doi.org/10.5539/jms.v8n3p16

\begin{abstract}
Brand management is a relatively new topic in marketing literature and it is considered by several researchers, academics and professionals, as one of the most important business strategies that allow not only a significant growth of the business performance of small enterprises, but also their continuity in the market where they participate. Similarly, brand management has also been analyzed and discussed at the core of enterprises and there are relatively few investigations that focus on small enterprises, and there are even less researches carried out in developing countries. For these reasons, the main goal of this empirical research is the analysis and discussion of the effects of brand management on the level of business performance in small enterprises, by using a sample of 300 small firms and by implementing a model of structural equations of second order, that can provide a deeper understanding of the current relation between brand management and business performance. The results obtained show that brand management has a positive and significant in the level of business performance in small enterprises.
\end{abstract}

Keywords: brand management, business performance, small business

\section{Introduction}

Brand management is considered in the marketing literature as an intangible resource that has a significant impact in business performance (Rao et al., 2004; Morgan \& Rego, 2009), since consumers often establish a good relation with the brand of products they buy (Park et al., 1986; Fournier, 1998; Thomson et al., 2005; Schau et al., 2009), which turns into a significant increase in the sales of brands (Park et al., 2010), as well as a reduction in the prices of products or services and in the marketing costs (Mizik \& Jacobson, 2008). Therefore, it is possible to state that the business performance, especially in small enterprises, depends mostly on the level of brand management that they have (Park et al., 2013).

In this regard, the impact created by brand management in the business performance is one of the most interesting topics among executives and managers of companies, mostly from small business, who still do not understand clearly the efficiency and the activities implied in brand management, as well as its contribution and value in the supply chain (Madden et al., 2006). For this reason, managers from different enterprises, including some small business, have focused an important part of their effort in investing more and more resources in the development of markets, that have a high level of financial and business performance for their products (Rust et al., 2004; Morgan \& Rego, 2009), which could contribute significantly to the financial health of the organization and improve the marketing capacities of enterprises, that have a higher level of influence in business performance (Dunes \& Pras, 2017).

However, several managers of enterprises, including small business, have some difficulties to measure the impact that brand management practices have in the return of their investments, just as it happens with the success of marketing activities (State of Marketing, 2015). As a result of this, the use of brand management as one of the main variables that influences in the business performance, will depend mostly on the ability of the marketing department in enterprises, especially in small business, to show the contribution that it creates in both the market and investment returns (Verhoef \& Leeflang, 2009), as well as the profit margin for stake holders or owners of organizations. That is why it is expected that brand management provide the necessary information in 
a short-term in order to have a better understanding of its efficiency in enterprises (Dunes \& Pras, 2017).

Additionally, researchers, academics and professionals in the field of marketing have to aim their efforts as well as their theoretical and empirical investigations to provide evidence that can show the importance of brand management in both the effectiveness of marketing activities and the business performance (Cui et al., 2014). Subsequently, researchers and academics have to provide in short-term evidence that verifies that brand management can help to the development of the perspectives of business performance in the long run (Tyagi \& Sawhney, 2010). Furthermore, brand management needs to provide empirical evidence that it can be understood and assimilated by enterprise managers, especially those from small business, as well as its impact not only in the brand performance itself of the products of the organization but in the business performance as well.

In this set of ideas, it is very important that researchers, academics and professionals in the field of marketing commit themselves to carry out studies or investigation projects that provide sound knowledge about the importance and relation of brand management (Aaker \& Joachimsthaler, 2000), with all the components that improve significantly both the brand and business performance (Dunes \& Pras, 2013; Coleman et al., 2015). In this regard, considering that are few published investigations in the literature that analyze the link between brand management and business performance, the main contribution of this empirical research is the analysis and discussion of brand management in the business performance of small business in a developing country, as it is the case of Mexico, just as recommended by Park et al. (2013), Veljkovic and Kalicanin (2016), as well as Dunes and Pras (2017).

\section{Method}

Brand management and the added value it creates in the business performance is considered in the current literature in the field of marketing, as one of the most important intangible resources that produce many competitive advantages in enterprises, and particularly in small business (Djuricin et al., 2013). Additionally, according to Keller and Lehmann (2006), the effects of brand management of organizations can usually be perceived in three levels: in the market of clients, in the market of products and in the financial market. This is why it is importance of brand management so it can be considered not only as a versatile construct, but also as one of the most important assets that produce a higher level of business performance as well as more value for the company (Narayan, 2012).

However, even when there are some published researches in the literature that have found a positive and significant influence between brand management and business performance (Lee et al., 2008; Santos-Vijande et al., 2013), they have three main limitations. The first one refers to the fact that brand management has not been analyzed regarding its influence in the target business performance, particularly the financial return, which is considered for several researchers and academics as critical element (Morgan \& Rego, 2009; Verhoef \& Leeflang, 2009; Feng et al., 2015). The second limitation is that brand management has been practically analyzed and discussed from the perspective focused on products or services of enterprises, but it has not been considered the influence of both constructs in the business performance (Veloutsou \& Panigyrakis, 2001; Dunes \& Pras, 2013).

The third limitation refers particularly to the fact that brand management has been generally measured as a reflective construct, and it has been adapted according to the activity field that is analyzed. Moreover, in some of the published studies where the link between brand management and business performance was analyzed, some of the dimensions of brand management have not been considered (Lee et al., 2008), or they have eliminated completely (Santos-Vijande et al., 2013), such as, for example, the dimensions of culture, organization and implementation (Lee et al., 2008; Santos-Vijande et al., 2013; Dunes \& Pras, 2013). Consequently, it is necessary that researchers and academics focus their investigations about brand management and its link with business performance, by using a scale that considers formative and comprehensive elements (Dunes \& Pras, 2017).

In this regard, there are some published investigations in the current literature in the field of marketing that have analyzed and discussed the influence of brand management in the business performance, but it is important to emphasize that the impact of brand management has not been the same in these researches. For example, de Chernatony (2001) identified five variables that affect significantly the success of brand management: 1) company (culture, internal communication, staff commitment, and so on); 2) dealers (goals alignment, power of balance, and so on); 3) clients (decision making process); 4) rivalry (strategic analysis of the competition) and; 5) macro-environment (future economic and social policies as well as technological change).

On the other hand, Wong and Merrilees (2007), in a research carried out in 403 enterprises in Australia, concluded that the marketing strategy and the level of innovation have a positive, significant influence in brand management and business performance. Additionally, in a different investigation, Wong and Merrilees (2008) analyzed the influence of different factors of brand orientation, such as the orientation towards the brand and 
innovation in which they found a positive, significant relation with brand performance and, at the same time, this was considered as a factor that determines in a positive and significant way the business performance in a high percentage. However, the barriers towards the brand had a negative impact in brand orientation.

Similarly, Lee et al. (2008), in a study carried out in Korea, found a positive, significant link between brand management and the performance of clients, which they called business performance (received market fee and return of the investment received). Furthermore, Burmann et al. (2009) concluded in their research that the commitment of the brand and the behavior of the brand of the cities have a close link with brand management, that is, according to these researchers, a higher commitment of the brand transforms into a higher behavior of the brand of the cities, which produces a strong commitment with brand management which eventually creates a higher level of business performance.

Also, M'zungu et al. (2010) implemented a model of three stages of brand management (the adoption of an orientation towards the brand; the internal brands; and the creation of a consistent brand), which allows not only to build the equity of the brand of the products of enterprises, but also to protect them which creates a higher level of business performance. Similarly, Gisip and Harun (2013) developed a theoretical concept of the background and results of brand management and proposed four essential dimensions for the measurement of brand management: a) relation of the brand with the culture and the organization; b) the knowledge and education of the brand; $c$ ) the marketing capacities; and $d$ ) the innovation and orientation of the brand as well as finding a positive and significant relation between brand management and business performance.

Additionally, Santos-Vijande et al. (2013) concluded in a research carried out in service enterprises from Spain, that there is a positive and highly significant relation between brand management and business performance. Likewise, Lennartz et al. (2015) used a multi-item scale for the measurement of the perception of the strength of the brand, the association of the brand and the business performance of the four instruments of marketing-mix (product, price, place and promotion). The results obtained show that brand management [measured with two factors: 1) sustainability and corporate government; and 2) innovation and expertise], and the perception of the product and the distribution have a positive, significant impact in both the results and the business performance.

In another set of ideas, Srinivasan and Hanssens (2009) concluded in their research that the improvement in the equality of clients, the brand and the brand management are closely linked with business performance Similarly, some of the few authors that have analyzed and discussed the relation between brand management and business performance, have usually considered business performance from the perspective of two essential factors: those associated to the growth of enterprises (getting new clients, barriers to deter competitors, growth of the same groups of products or categories of new products, easy access to new markets), and the ones regarding profit (loyalty of the brand, higher prices, low elasticity of prices, promotional efficiency, better position to negotiate in the marketing channels) (Veljkovic, 2010).

Correspondingly, some researchers and academics have measured the value of the brand in a traditional way based on the observation of income profitability. They have concluded that brand management contributes in a significant way to the achievement of business performance (Ailawadi et al., 2001; Huang \& Sarigollu, 2014), whereas Yeung and Ramasamy (2008) found in their paper a close link between value and brand management as well as different ratios of profitability and measurements of business performance. Moreover, other authors have focused their researches on brand management and its impact in business performance, since they consider that a strong brand management can increase the value of the enterprise significantly, especially in small ones, which in turn could create a continuous cash flow and reduce the costs of capital that would give firms a higher level of business performance (Doyle, 2000).

Additionally, carried out an analysis of the existing relation between expenses in broadcasting and advertising and the market value of small companies. They concluded that the brand management activities have a strong, positive and significant association with the business performance of the small enterprises. Similar results were obtained by Verbeteeten and Vijn (2010), when they noticed in their research paper a close tie between equity, brand management and business performance. Thus, it is possible to state that different activities of brand management are very important to attain more and better levels of business performance in all enterprises from different sizes, sectors and industries (Veljkovic \& Kalicanin, 2016).

To sum up, small enterprises that have brand activities and brand management as an important part of business strategies will have more opportunities to achieve a higher level of business performance (Veljkovic \& Kalicanin, 2016). This can be seen in the investigations carried out by different researchers, academics and professionals in the field of marketing, such as the research made by Harter et al. (2005), who proved that the good brand management of European banks enabled an investment return of $19 \%$ in comparison to the one obtained by the 
financial sector which averaged $18 \%$ whereas the excellent brand management of manufacturing enterprises, especially the small ones, obtained a profitability margin of $17 \%$ in comparison to the enterprises of the sector which was around $10 \%$.

Finally, Grosmark and Melin (2011) found in their research that roughly 15\% of all the margin of profitability obtained by enterprises, can be explained through the level of brand management whereas Kalicanin et al. (2015) carried out an investigation in enterprises from Serbia where they analyzed the link between brand management and business performance. They found that brand orientation and brand management have a high, positive and significant correlation in business performance. Therefore, considering the information mentioned earlier, it is possible to establish the following research hypothesis:

\section{H1: The higher level of brand management, higher level of business performance.}

An empirical research in small enterprises was carried out in Aguascalientes (Mexico), in order to answer the research hypothesis by using the business directory of the Sistema de Información Empresarial Mexicano (System of Mexican Business Information), which had 1,400 small enterprises, each one containing from 5 to 250 employees at the of January, 2017. Similarly, the instrument of data collection (survey) was designed to be answered specifically by managers and/or owners of small enterprises. It was carried out as a personal interview with a sample of 300 small firms selected through a random sampling with a maximum error of $\pm 5 \%$ and a level of reliability of $95 \%$, which represented slightly over $21 \%$ of all the small enterprises registered in Aguascalientes (Mexico). Finally, it is also important to mention that the survey took place between February and April of 2017.

Likewise, the scale developed by Baumgarth (2010) was used for the measurement of brand management in small enterprises. He considered that brand management can be measured through four factors or dimensions: Value, which was measured through a scale of five items; Norms, which were measured through a scale of six items; Artifacts, which were measured through a scale of four items; and Behaviors, which were measured through a scale of four items. All the items of the four factors or dimensions were measured through scales based on a Likert-type scale of five positions from " $1=$ completely disagree" to " $5=$ completely agree" as limits. Furthermore, the business performance was measured through a three-item scale (1: return of the investment, 2 : earnings compared with the competitors, and 3: market participation compared with the competitors). This scale was adapted from Tan and Litschert (1994), and measured through a Likert-type scale of five positions from " 1 = completely disagree" to " $5=$ completely agree" as limits.

Similarly, a Factorial Confirmatory Analysis of Second Order (FCASO) was carried out to evaluate the reliability and validity of the scales of brand management and business performance, by using the method of maximum likelihood with the software EQS 6.2 (Bentler, 2005; Brown, 2006; Byrne, 2006). Furthermore, the reliability was evaluated with Cronbach's alpha, the Composite Reliability Index (CRI) (Bagozzi \& Yi, 1988). The results obtained of the implementation of the FCASO are shown in Table 1 and show that the mode analyzed has a good adjustment of data $\left(S-B X^{2}=1,071.946 ; d f=198 ; p=0.000 ; N F I=0.883 ; N N F I=0.886 ; C F I=0.902\right.$; $R M S E A=0.079$ ). The values of Cronbach's alpha and the CRI are higher than 0.7, which indicates the presence or reliability in the scales of brand management and business performance (Nunally \& Bernstein, 1994; Hair et al., 1995).

Additionally, the results obtained from the FCASO indicate that all the items of the factors related are significant $(\mathrm{p}<0.01)$. The value of all the standardized factorial loads is higher and 0.6 (Bagozzi \& Yi, 1988), and the Extracted Variance Index (EVI) of each pair of constructs of the theoretical model of brand management and business performance, has a value above 0.5 (Fornell \& Larcker, 1981). These values indicate that the theoretical model has a good adjustment of data and provide evidence of the presence of convergent validity. 
Table 1. Internal consistency and convergent validity of the theoretical model

\begin{tabular}{|c|c|c|c|c|c|c|}
\hline Variable & Indicator & Factor Load & $\begin{array}{l}\text { Robust } \\
\text { t-Value }\end{array}$ & $\begin{array}{l}\text { Cronbach's } \\
\text { Alpha }\end{array}$ & CRI & EVI \\
\hline \multirow{5}{*}{$\begin{array}{l}\text { Value } \\
\text { (F1) }\end{array}$} & VM1 & $0.968 * * *$ & $1.000^{\mathrm{a}}$ & \multirow{5}{*}{0.978} & \multirow{5}{*}{0.979} & \multirow{5}{*}{0.903} \\
\hline & VM2 & $0.971 * * *$ & 78.359 & & & \\
\hline & VM3 & $0.960 * * *$ & 46.165 & & & \\
\hline & VM4 & $0.941 * * *$ & 36.618 & & & \\
\hline & VM5 & $0.909 * * *$ & 29.422 & & & \\
\hline \multirow{6}{*}{$\begin{array}{l}\text { Norms } \\
\text { (F2) }\end{array}$} & NM1 & $0.880 * * *$ & $1.000^{\mathrm{a}}$ & \multirow{6}{*}{0.928} & \multirow{6}{*}{0.929} & \multirow{6}{*}{0.686} \\
\hline & NM2 & $0.855^{* * *}$ & 32.894 & & & \\
\hline & NM3 & $0.868 * * *$ & 23.272 & & & \\
\hline & NM4 & $0.837 * * *$ & 20.262 & & & \\
\hline & NM5 & $0.776^{* * *}$ & 19.015 & & & \\
\hline & NM6 & $0.745^{* * *}$ & 17.398 & & & \\
\hline \multirow{4}{*}{$\begin{array}{l}\text { Artifacts } \\
\text { (F3) }\end{array}$} & AM1 & $0.966^{* * *}$ & $1.000^{\mathrm{a}}$ & \multirow{4}{*}{0.984} & \multirow{4}{*}{0.985} & \multirow{4}{*}{0.944} \\
\hline & AM2 & $0.974 * * *$ & 74.575 & & & \\
\hline & AM3 & $0.979 * * *$ & 51.702 & & & \\
\hline & AM4 & $0.968 * * *$ & 44.098 & & & \\
\hline \multirow{4}{*}{$\begin{array}{l}\text { Behaviors } \\
\text { (F4) }\end{array}$} & CM1 & $0.952 * * *$ & $1.000^{\mathrm{a}}$ & \multirow{4}{*}{0.942} & \multirow{4}{*}{0.943} & \multirow{4}{*}{0.807} \\
\hline & $\mathrm{CM} 2$ & $0.930 * * *$ & 37.119 & & & \\
\hline & CM3 & $0.892 * * *$ & 29.990 & & & \\
\hline & CM4 & $0.813 * * *$ & 22.478 & & & \\
\hline \multirow{4}{*}{ Brand Management } & F1 & $0.788 * * *$ & 6.103 & \multirow{4}{*}{0.888} & \multirow{4}{*}{0.889} & \multirow{4}{*}{0.667} \\
\hline & F2 & $0.873 * * *$ & 7.436 & & & \\
\hline & F3 & $0.749 * * *$ & 6.273 & & & \\
\hline & F4 & $0.850 * * *$ & 8.553 & & & \\
\hline \multirow{3}{*}{ Business Performance } & REN1 & $0.854 * * *$ & $1.000^{\mathrm{a}}$ & \multirow{3}{*}{0.887} & \multirow{3}{*}{0.888} & \multirow{3}{*}{0.729} \\
\hline & REN2 & $0.958 * * *$ & 17.575 & & & \\
\hline & REN3 & $0.734 * * *$ & 13.927 & & & \\
\hline \multicolumn{7}{|c|}{$S-B X^{2}(\mathrm{df}=198)=1,071.946 ; \mathrm{p}<0.000 ; \mathrm{NFI}=0.883 ; \mathrm{NNFI}=0.886 ; \mathrm{CFI}=0.902 ; \mathrm{RMSEA}=0.079$} \\
\hline
\end{tabular}

Moreover, the analysis of the discriminant validity of the theoretical model of brand management and business performance was measured by two tests, which are shown in Table 2. The first one is the Reliability Interval Test proposed by Anderson and Gerbing (1988), which establishes that with an interval of $95 \%$ of reliability none of the individual latent elements of the matrix of correlation must have a value of 1.0. Secondly, the Extracted Variance Test, proposed by Fornell and Larcker (1981) establishes that the extracted variance between each pair of constructs is lower than their corresponding EVI. Therefore, based on the results obtained from both tests, it can be concluded that that both tests provide enough evidence of the presence of discriminant validity.

Table 2. Discriminant validity of the theoretical model

\begin{tabular}{lll}
\hline Variables & Brand Management & Business Performance \\
\hline Brand Management & $\mathbf{0 . 6 6 7}$ & 0.158 \\
Business Performance & $0.266-0.530$ & $\mathbf{0 . 7 2 9}$ \\
\hline
\end{tabular}

The diagonal represents the Extracted Variance Index (EVI), whereas above diagonal the part of the variance is shown (correlation). Below diagonal the estimation of factors correlation is depicted with a confidence interval of $95 \%$.

\section{Results}

In order to answer the research hypothesis established in this empirical research, a model of structural equations of second order was applied with software EQS 6.2 (Bentler, 2005; Byrne, 2006; Brown, 2006), in which the nomological validity of the theoretical model of brand management and business performance, was examined through the Chi-square test which compared the results obtained between the theoretical model and the measurement model. Such results indicate that the differences between both models are not significant, which can offer an explanation of the relationships observed among the latent constructs (Anderson \& Gerbing, 1988; 
Hatcher, 1994). Table 3 shows the results in a more detailed way regarding the implementation of the model of structural equations of second order.

Table 3. Results from the structural equations model

\begin{tabular}{lccc}
\hline Hypothesis & Structural Relationship & $\begin{array}{l}\text { Standardized } \\
\text { Coefficient }\end{array}$ & $\begin{array}{l}\text { Robust } \\
\text { t-Value }\end{array}$ \\
\hline $\begin{array}{l}\text { H1: The higher level of brand } \\
\text { management, higher level of business } \\
\text { performance. }\end{array}$ & Brand M. $\rightarrow$ Business P. & $0.651^{* * *}$ & 13.927 \\
\hline$S-B X^{2}(\mathrm{df}=194)=1,016.365 ; \mathrm{p}<0.000 ; \mathrm{NFI}=0.889 ; \mathrm{NNFI}=0.890 ; \mathrm{CFI}=0.908 ; \mathrm{RMSEA}=0.079$ & \\
$* * *=\mathrm{P}<0.01$.
\end{tabular}

Table 3 shows the results obtained from the research hypothesis $\mathbf{H}_{\mathbf{1}}(\beta=0.651, \mathrm{p}<0.01)$. They indicate that brand management has significant, positive effects in the business performance. With this, it is possible to establish that the different activities of brand management adopted and implemented by small enterprises have a positive effect in their level of business performance.

\section{Discussion}

On one hand, the brand management of products and services created by small enterprises can be measured through four constructs: value, norms, artifacts and behavior. Thus, it can be stated that brand management in small Mexican enterprises is practically carried out through, the value given by clients and consumers to the products or services generated by small enterprises and the norms established by companies, as well as the artifacts used by small corporations in order to make the brands of their products and services more attractive by both the internal and external behavior of the organization regarding the brand. All this allows that different consumers and clients may prefer to choose some specific brands of products or services.

On the other hand, considering that a high percentage of small enterprises (if not all) have as their main target and goal to obtain a significant increase in the level of business performance, in order to achieve the expected outcome they have to redirect their current business strategies, and also create and implement new business strategies such as brand management, which must be adapted to their own needs and organizational structure. Therefore, it is possible to conclude that brand management is considered in the current literature in the field of marketing by several researchers and academics, as one of the current business strategies that best adapt to the organizational structure of small enterprises in order to achieve a significant increase in their level of business performance, as well as to survive in the market where they participate in this moment.

Similarly, the results obtained in this empirical research have different implications that are necessary to establish at this point. The first one is that small enterprises from developing countries or with an emerging economy (as it is the case of Mexico), usually do not register the commercial brand of their products or services. Therefore, managers of enterprises, who are mostly the owners, have to make an effort to register the intellectual property copyright of the brand of their products or services, which will allow them to exploit it and have the opportunity of achieving a higher position in the market where they participate, as well as a significant increase of their level of business performance.

A second implication originated from these results is that small enterprises do not have to consider brand management just as another business strategy of the organization, but rather as a series of everyday activities that they need to develop since brand management requires from managers of small enterprises, to make constant changes so all employees and workers of the organization get involved completely in the brand management of products or services of the enterprise. In this regard, in order to achieve a good brand management, it is necessary that managers involve all the functional areas or departments of the organization in these activities, which in turn will enable small enterprises to attain a higher level of business performance.

A third implication of the results obtained is that managers of small enterprises from developing countries, will have to implement the necessary and required training programs regarding brand management for executives, employees and workers or take advantage of the different training programs offered by business organizations, international associations and government branches of the three levels related to brand management and intellectual property copyright, as this will allow small enterprises from developing countries to increase significantly their level of business performance, as well survive and continue in the market where they currently participate. 
Finally, the last implication of the results obtained is that managers of small enterprises have to create an organizational environment that promotes the development and implementation of activities, that imply brand management in all the organization in order to eliminate gradually the attitudes of workers and employees that are set in their ways. With this, all the staff of the enterprise will adopt a positive and proactive attitude towards the activities required by brand management. If all managers or owners of small enterprises do not have the ability to create the changes that demand an efficient and effective brand management, then not only the level of business performance will be at risk but also the very survival of the enterprise.

Additionally, this empirical research has some limitation that is necessary to mention. The first one is about the sample used as only small enterprises that had between 5 and 250 workers were considered. That is why future investigations will have to consider small enterprises with less than 5 workers in order to confirm the results obtained. The second limitation is that the questionnaire applied to collect the data only considered small businesses in the state of Aguascalientes (Mexico). Future researches will need to apply the questionnaire to small enterprises from all the country and even other countries in order to verify if the results obtained are similar.

A third limitation are the scales used to measure both the brand management and the business performance, as the scale used only contains four dimensions or factors with 19 items for the measurement of brand management and three items to measure business performance. The following investigations will need to use a different scale for the measurement of both constructs to confirm the results obtained. A fourth limitation is that only qualitative variables were considered to measure both the brand management and the business performance, so in the future it will be necessary to consider hard data or quantitative variables to prove if there are any significant differences in the results obtained from small enterprises.

A fifth limitation is that the instrument applied to collect data only considered managers and/or owners of small enterprises. This created the assumption in the research paper that these executives had a deep understanding about brand management activities and the business performance of the organization. Future research papers will need to apply the same questionnaire to employees and workers in order to confirm the results obtained. Finally, the last limitation is that a high percentage of small enterprises considered that the information requested was confidential, so the results obtained do not necessarily reflect the reality that this type of enterprises have regarding brand management and business performance.

\section{References}

Aaker, D. A., \& Joachimsthaler, E. (2000). Brand Leadership. New York, NY: Free Press.

Ailawadi, K. L., Lehmann, D. R., \& Neslin, S. A. (2001). Revenue premium as an outcome measure of brand equity. Journal of Marketing, 67(10), 1-17.

Anderson, J., \& Gerbing, D. (1988). Structural equation modelling in practice: A review and recommended two-step approach. Psychological Bulletin, 13, 411-423.

Bagozzi, R. P., \& Yi, Y. (1988). On the evaluation of structural equation models. Journal of the Academy of Marketing Science, 16(1), 74-94. http://dx.doi.org/10.1007/BF02723327

Baumgart, C. (2010). Living the brand: Brand orientation in the business-to-business sector. European Journal of Marketing, 44(5), 653-671.

Bentler, P. M. (2005). EQS 6 structural equations program manual. Encino, CA: Multivariate Software.

Brown, T. (2006). Confirmatory factor analysis for applied research. New York, NY: The Guilford Press.

Burmann, C., Zeplin, S., \& Riley, N. (2009). Key determinants of internal brand management success: An exploratory empirical analysis. Journal of Brand Management, 16(4), 264-284. http://dx.doi.org/10.1057/bm.2008.6

Byrne, B. (2006). Structural equation modelling with EQS, basic concepts, applications, and programming (2nd ed.). London: LEA Publishers.

Coleman, D. A., de Chernatony, L., \& Christodoulides, G. (2015). B2B service brand identity and brand $\begin{array}{llll}\text { performance. European Journal of Marketing, 49(7/8), 1139-1162. } & \text {. }\end{array}$ http://dx.doi.org/10.1108/EJM-03-2013-0154

Conchar, M. P., Melvin, R. C., \& Zinkhan, G. M. (2005). Market valuation models of the effect of advertising and promotional spending: A review and meta-analysis. Journal of the Academy of Marketing Science, 33(4), 445-460. http://dx.doi.org/10.1177/0092070305277693 
Cui, A. P., Hu, M. Y., \& Griffith, D. A. (2014). What makes a brand manager effective? Journal of Business Research, 67(2), 144-150. http://dx.doi.org/10.1016/j.jbusres.2012.11.002

de Chernatony, L. (2001). A model for strategically building brands. Journal of Brand Management, 9(1), 32-44. http://dx.doi.org/10.1057/palgrave.bm.2540050

Djuricin, D., Janosevic, S., \& Kalicanin, D. (2013). Menadzment i Strategija. Beograd: Ekonomski Fakultet.

Doyle, P. (2000). Value-Based Marketing: Marketing Strategies for Corporate Growth and Shareholder Value. Chichester: John Wiley \& Sons.

Dunes, M., \& Pras, B. (2013). Practices in the brand management system: Identification and considerations for five business sectors. Journal of Product \& Brand Management, 22(7), 444-461. http://dx.doi.org/10.1108/JPBM-09-2013-0396

Dunes, M., \& Pras, B. (2017). The impact of brand management system on performance across service and product-oriented activities. Journal of Product \& Brand Management, 26(3), 294-311. http://dx.doi.org/10.1108/JPBM-09-2015-0995

Feng, H., Morgan, N. A., \& Rego, L. L. (2015). Marketing department power and firm performance. Journal of Marketing, 79(5), 1-20. http://dx.doi.org/10.1509/jm.13.0522

Fornell, C., \& Larcker, D. (1981). Evaluating structural equation models with unobservable variables and measurement error. Journal of Marketing Research, 18(1), 39-50. http://dx.doi.org/10.2307/3151312

Fournier, S. (1998). Consumers and their brands: Developing relationship theory in consumer research Journal of Consumer Research, 24(3), 343-373.

Gisip, I. A., \& Harun, A. (2013). Antecedents and outcomes of brand management from the perspective of resourced based view (RBV) theory. Mediterranean Journal of Social Sciences, 4(10), 432-438.

Gromark, J., \& Melin, F. (2011). The underlying dimensions of brand orientation and its impact on financial performance. Journal of Brand Management, 18(6), 394-410. http://dx.doi.org/10.1057/bm.2010.52

Hair, J. F., Anderson, R. E., Tatham, R. L., \& Black, W. C. (1995). Multivariate data analysis with readings. New York, NY: Prentice-Hall.

Harter, G., Koster, A., Peterson, M., \& Stomberg, M. (2005). Managing brands for value creation. Retrieved from http://www.boozallen.com/media/file/Managing_Brands_for_Value_Creation.pdf

Hatcher, L. (1994). A step-by-step approach to using the SAS system for factor analysis and structural equation modelling. Cary, NC: SAS Institute Inc.

Huang, R., \& Sarigollu, E. (2014). Assessment of brand equity measures. International Journal of Marketing Research, 56(6), 783-806.

Kalicanin, D. J., Veljkovic, S., \& Bogetic, Z. (2015). Brand orientation and firm performance nexus. Industrija, 43(1), 155-173. http://dx.doi.org/10.5937/industrija43-7592

Keller, K. L., \& Lehmann, D. (2006). Brands and branding: Research findings and future priorities. Marketing Science, 25(6), 740-759. http://dx.doi.org/10.1287/mksc.1050.0153

Lee, J., Park, S. Y., Baek, I., \& Lee, C. S. (2008). The impact of the brand management system on brand performance in B-B and B-C environments. Industrial Marketing Management, 37(7), 848-855. http://dx.doi.org/10.1016/j.indmarman.2008.04.005

Lennartz, E., Fischer, M., Krafft, M., \& Peters, K. (2005). Drivers of B2B brand strength-insights from an international study across industries. Schmalenbach Business Review, 67(1), 114-137.

M'zungu, S. D. M., Merrilees, B., \& Miller, D. (2010). Brand management to protect brand equity: A conceptual model. Brand Management, 17(8), 605-617. http://dx.doi.org/10.1057/bm.2010.15

Madden, T. J., Fehle, F., \& Fournier, S. M. (2006). Brands matter: An empirical demonstration of the creation of the shareholder value through branding. Journal of the Academy of Marketing Science, 34(2), 224-235. http://dx.doi.org/10.1177/0092070305283356

Mizik, N., \& Jacobson, R. (2008). The financial value impact of perceptual brand attributes. Journal of Marketing Research, 44(1), 15-32.

Morgan, N. A., \& Rego, L. L. (2009). Brand portfolio strategy and firm performance. Journal of Marketing, 73(1), 59-74. http://dx.doi.org/10.1509/jmkg.73.1.59 
Narayan, G. (2012). Brand valuation: A strategic tool for business. Journal of Brand Management, 9(3), 55-64.

Nunnally, J. C., \& Bernstein, I. H. (1994). Psychometric theory (3rd ed.). New York: McGraw-Hill.

Park, C. W., Eisingerich, A. B., Pol, G., \& Park, J. W. (2013). The role of brand logo in firm performance. Journal of Business Research, 66(1), 180-187.

Park, C. W., Jaworski, B. J., \& MacInnis, D. J. (1986). Strategic brand concept-image management. Journal of Marketing, 50(2), 135-145.

Rao, V. R., Agarwal, M. K., \& Dahlhoff, D. (2004). How is manifest-branding strategy related to the intangible vale of corporation? Journal of Marketing, 68(2), 126-141.

Rust, R. T., Abmer, T., Carpenter, G. S., Kumar, V., \& Srivastava, R. K. (2004). Measuring marketing productivity: Current knowledge and future directions. Journal of Marketing, 68(4), 76-89. http://dx.doi.org/10.1509/jmkg.68.4.76.42721

Santos-Vijandre, M. L., Del Rio-Lanza, A. B., Suarez-Alvarez, L., \& Diaz-Martín, A. M. (2013). The brand management system and service firm competitiveness. Journal of Business Research, 66(2), 148-157.

Schau, H. J., Muñiz, A. M., \& Arnould, E. J. (2009). How brand community practices create value? Journal of Marketing, 73(3), 30-51.

Srinivasan, S., \& Hanssens, D. (2009). Marketing and firm value: Metrics, methods, findings, and future directions. Journal of Marketing Research, 46(6), 293-312.

State of Marketing. (2015). 2015 state of marketing: Insights from over 5,000 global marketers. Retrieved from http://secure.sfdcstatic.com/assets/pdf/datasheets/mc_2015stateofmarketing.pdf

Tan, J., \& Litschert, R. (1994). Environment-strategy relationship and its performance implications: An empirical study of Chinese electronics industry. Strategic Management Journal, 15(1), 1-20.

Thomson, M., MacInnis, D. J., \& Park, C. W. (2005). The ties that bind: Measuring the strength of customers' emotional attachment to brands. Journal of Consumer Psychology, 15(1), 77-91. http://dx.doi.org/10.1207/s15327663jcp1501_10

Tyagi, R. K., \& Sawhney, M. S. (2010). High-performance product management: The impact of structure, process, competencies, and role definition. Journal of Product and Innovation Management, 27(1), 83-96. http://dx.doi.org/10.1111/j.1540-5885.2009.00701.x

Veljkovic, S. (2010). Brand Menadzment u Savremenim Trzisnim Uslovima. Beograd: Ekonomski Fakultet.

Veljkovic, S., \& Kalicanin, D. (2016). Improving business performance through brand management practice. Economic Annals, 41(208), 137-167.

Veloutsou, C., \& Panigyrakis, G. (2001). Brand teams and the brand management structure in pharmaceutical and other fast-moving consumer goods companies. Journal of Strategic Marketing, 9(3), 233-251. http://dx.doi.org/10.1080/09652540121770

Verbeeten, F., \& Vijn, P. (2010). Are brand-equity measures associated with business-unit financial performance? Empirical evidence from the Netherlands. Journal of Accounting, Auditing \& Finance, 25(4), 645-671. http://dx.doi.org/10.1177/0148558X1002500408

Verhoef, P. C., \& Leeflang, P. S. H. (2009). Understanding the marketing department's influence within the firm. Journal of Marketing, 73(2), 372-383. http://dx.doi.org/10.1509/jmkg.73.2.14

Wong, H. Y., \& Merrilees, B. (2008a). Closing the marketing strategy to performance gap: The role of brand orientation. Journal of Strategic Marketing, 15(12), 387-402.

Wong, H. Y., \& Merrilees, B. (2008b). The performance benefits of being brand-orientated. Journal of Product \& Brand Management, 17(6), 372-383.

Yeung, M., \& Ramasamy, B. (2008). Brand value an firm performance nexus: Future empirical evidence. Journal of Brand Management, 15(5), 322-335. http://dx.doi.org/10.1057/palgrave.bm.2550092

\section{Copyrights}

Copyright for this article is retained by the author, with first publication rights granted to the journal.

This is an open-access article distributed under the terms and conditions of the Creative Commons Attribution license (http://creativecommons.org/licenses/by/4.0/). 